\title{
Traditional Social Security in the Fisherman Communities in Small Islands and Coastal Region South Sulawesi
}

\author{
Mahmud Tang \\ Department of Anthropology, Hasanuddin University, Makassar, Indonesia \\ Corresponding author: mahmud.tang@yahoo.com
}

\begin{abstract}
This paper discussed about traditional social securities in solving the problems which is faced by the poor in the fishing communities. This data is obtained from the results of our early research in the Salemo and Sabangko small islands Pangkep regency and in the coastal Madello village Barru regency. The implementation of the government's social assistance projects to increase the income of fishermen, quite unsuccessfully. Beside that there are traditional social securities which are based on customary rules religious doctrine. and religious institutions. Until nowadays, the traditional social securities still relied on the fishermen community on the coast and small islands in the countryside of South Sulawesi, though it has undergone many changes.
\end{abstract}

Keywords—fishermen communities, poverty, social security

\section{INTRODUCTION}

In the history of mankind, since in the past time until nowadays, people always struggled to fulfill the basic needs in life. As stated by Bakari "Social And Economic Insecurity Has Historically Been Endemic To Human Societies" [2] in Indonesia, poverty can be found everywhere, including in South Sulawesi; especially in coastal regions and small islands $[10,11,1]$

In the framework of poverty reduction, the Government of Indonesia look at poverty as a problem of development of social welfare. Therefore, the poverty which is mainly suffered by the poor is a major problem that the reduction of it could not be postponed and should be a top priority in the implementation of social welfare development. Empowerment of the poor is one of the national strategic efforts in realizing a populist economic system social justice and protect human rights, especially in the fulfillment of basic human needs [5]

A variety of policies and efforts that have been undertaken by the Government in the framework of poverty reduction programs, such as an increase in the income of small farmers and Fishers (P4K), joint venture (KUBE), presidential instruction Program (IDT) Villages Left $[9,11]$. In general, it is hard to say that the social assistance which has been given by the Government is succeed; the amount of assistance provided is too small and often to be in wrong target. The purpose of writing this paper is to describe the traditional social securities which is provided by family, neighbors, patron-client relationships and the institutions of religion. As Anthropology study, it will be analyzed the cultural systems that regulate it which comes from custom, and religious rules deriving from the teachings of Islam.

The definition of conventional social securities is from the International Labour Organization (ILO) which means, "the protection which the society provides for its members, through a series of public measures, against the economic and social distress that otherwise would be caused by the stoppage or substantial reduction of earnings resulting from sickness, maternity, employment injury, unemployment, old age and death; the provision of medical care; and the provision of subsidies for families with children" [4].

By viewing the field study on social securities in Indonesia the definition from the ILO could be said to be too narrow. It is limited on provision that provided by "the Government on hard situation". The definition above does not include the provision of assistance towards the same needs which are provided by individuals or social groups other than from the government, such as family, neighbours, the pinggawa (patron), friends and religious institutions. Restrictions on aid of the government alone does not give a complete picture, as it is not showing the importance of analyzing the role played by the various parties and other institutions [3, 4]. In short, that the definition of conventional social securities from the above, the ILO does not fit the context of the socio-economic and political realities of the less developed countries, which are still not being integrated in the formal sector economic sectors and are mostly poor, many very poor [6]

In this paper the social securities will be seen as an analytical concept that deals with a particular "social function". The term social securities is used to refer to the problem of social problems. In a broad sense of social securities may refer to efforts of government institutions, individuals, family groups, residents of one village, and private sector to address issues of basic needs of members of the community such as adequate food, housing, health care, education and clean water to allow them to meet the standards of life corresponding to the norms of society. As for the traditional social securities are securities which the social source does not come from the government institutions which are given or received from the existence of social relationships such as kinship, friendship, neighborhood, patron-client relationship and the institution of religion. 
As with the concept of social securities, the concept of poverty also received attention from a lot of experts, especially from social scientists who will become the reference in the paper. From among the social sciences, among others, I.P. Getubig briefly defines the concept of "the poor" as follows: "Those whose basic needs are not adequately met". furthermore Getubig mention anything which becomes "social security need" of the poor that, among others, as follows: "Adequate and stable income from wage or self-employment; basic needs: health care services, nutrition, shelter, education (basic education, skill training) clean water, sanitation facilities and supply" [6].

From the definition above, the "poor people" in the fishing communities can be limited as "people who are not able to meet the basic needs for decent life in accordance with the norms in the community". An overview of the life of the citizens of poor fishermen in places we can see, living in relatively shabby surroundings, their residence, their outfits simple versatile and it is important to be satiety, health conditions are very susceptible to various diseases, difficult to obtain clean water, etc. [11, 7].

\section{RESEARCH METHOD}

Methodologically, the research which became the source of the data of this paper is a descriptive qualitative. This research was conducted in the small islands Salemo and Sabangko in Pangkep Regency. Salemo Island is selected by purposive because the island is famous as the Islamic area, whereas Sabangko Island was chosen because nuanced syncretic. Other sources of data are the results of our research in Madello Village inhabited by a community of fishermen which is situated on the coast of Barru Regency. The village of Madello was chosen with consideration that the coastal village has a different characteristic with small islands. As ethnographic research is qualitative, data collected through literature study, participant observation and in-depth interview. This research was conducted in 2016 and preliminary research 2017 [12, 13].

\section{RESULT AND DISCUSSION}

\section{A. Adequate and Stable Income}

One of the criteria of poverty of the fisherman is his income is low and unstable. One source of help that really help the fishermen was sourced from individual i.e. from businessmen who called by the fishermen of the Salemo and Sabangko islands as Boss (called pinggawa lompo in Madello).

In 2016 there were a Boss famed as the entrepreneur of crabs stripping in Salemo island namely H. Arsyad. He built the dozens of fishermen for crab (pabbukkang) not only the fishing island of Salemo, but also from other islands. This boss is helping dozens of fishing crab with lent them the capital to purchase the equipment catch with an obligation to sell the results of her catch on the boss.

In addition to aid to pabbukkang (the crab fishers), crab entrepreneurs also opens up employment to dozens of girls from poor families in the island of Salemo. Those who are still in school began to work after one hour from the school until seven in the evening. Daughters (aged 12 years and more) who are working, who are generally from poor fishermen, families can earn between $\mathrm{Rp} 600,000$ to $\mathrm{Rp} 1.000 .000$,- per month. The opening of employment for the girl is typical of the island of Salemo and not found on the islands of Sabangko and Madello.

The crab entrepreneurs and some other people can afford to also open a business of seaweed in the rainy season. This effort also absorb much manpower and provide additional income to the family fisherman, especially for women who have no breadwinner (widows). This job lasted for six months from December to may with earnings of around Rp. 20.000 to Rp. 30.000 per day. In the village of Madello job opportunities for widows was given by a woman entrepreneur shredded fish. With a job that widows who are working can earn about $\mathrm{Rp}$. 500,000 per month.

\section{B. Basic Needs}

\section{Nutritions}

In addition of the rice aid for poor people from the government, people also get traditionally food substance social securities from various parties. On famine in which fishermen less produce catch crabs and fish, so it doesn't have the money to buy rice so they can be helped by the Paggadde people who sell daily necessities. The fishermen could buy rice from Paggadde are not cash.

Up to the year 2014 in the village of Madello farmers still cut rice with a sickle takes a lot of manpower, the fishermen were active mainly in rice harvest joined their boss so they can collect the harvest wages enough to be consumed during a years into the future. At this point the tradition of harvesting which involves family joined the fishermen no longer exists because of the power of man is replaced with the power of the engine. Nevertheless, there are still farmers who hand out rice to family members nearby.

In addition to help resources acquisition rice/grain as mentioned above, which is no less important to mention is the zakat fitrah in Ramadan. On the island of Salemo generally people share immediate Zakat to members of his kin were considered poor, particularly particularly widows, the elderly, infants and qur'an teachers, traditional midwife. In the month of Ramadan in 2017, an entrepreneur in Balikpapan send four tons of rice to the island of Salemo to doled out to 400 people, particularly to widows as zakat fitrah.

As for the need for a side dish, fish people can get some tail free of charge from the fisherman who caught the fish in large numbers. As a sign of joy they gave some to people coming to pick him up at the edge of the beach. Another way to acquire fish from a fisherman on the island of Salemo was buy 10 or 20 fish and given the additional extras some tail.

\section{Shelter}

On the small islands of Salemo and Sabangko, and the coast of Madello and Sumpang Minangae citizen of fishermen still contribute the work in the repair of their houses. On the 
island of Sabangko, a family from a burning house in 2016 ago established a permanent home with mutual help. Two other families established non-permanent home that most development processes are carried out cooperatively as well.

No one on the island of Salemo who have no place to live. People who do not have their own homes can get help somewhere to stay at home or in a home under the nearby family members without having to rent. Such a thing also occurred on the island of Sabangko and Madello, where children who are married are given a place to stay at home parents/in-laws. For the clean water, people who do not obtain fresh water from about themselves may take from the neighboring wells. In general people are free to come and take the wash water with the neighboring wells free.

\section{Health Care}

According to the experience of midwives on the Salemo island, even the patient could pay it by paying the instalment, but there is nothing more than a month their debt is paid off. It was probably paid off because they got donations from members of the relatives and neighbors at the aqiqah event which is generally done on the sevent or ninth day. Now in Madello, giving birth with the help of traditional midwife is paid $\mathrm{Rp} 250,000$ to $\mathrm{Rp}$. 500,000. - for the close family of the traditional midwife they only pay IDR 250,000. The cost for the patient who come to the doctor, usually got a donation from their close relatives and neighbor, both in service or money.

\section{Education}

Parents complain a lot reserved for school clothing costs, textbooks, the allowance of his sons. For assistance in the form of money people can still expect from close family (children and siblings). Other sources such as already mentioned above that the school children (female) are the first school in the secondary school and the high school on the island can be helped by the presence of Salemo access to earn wages from working in the company of a crab. In addition, although only twice in a single year during the Eid ul-Fitr and Eid al-Adha school children gain sedeqah of some people who gave money Rp. 5.000 - RP.10,000 to each child who visited his home.

\section{CONCLUSION}

Nowadays, as we see in the discussion above, the traditional social securities are still persisting in helping ease the burden of the needy of fulfilling a basic needs of community residents in coastal and small islands. Nevertheless, it is undeniable that traditional social securities could not overcome the difficulties of completely and permanently.

In terms of granting assistance to earn revenue that comes from crabs entrepreneurs, seaweed farmers and entrepreneurs tivoid languages, all of which can only be accessed by people who still have the energy to work, so it is not able to overcome the problems faced by the elderly who are unable to work anymore.
Nutritional needs of fulfillment problems have occurred the changes do not get the opportunity again to join the harvest on farmers because of the need of human labor has been replaced with the power of the engine. Help resources in contention is a staple ingredient of sellers still want to sell merchandise are not cash. In addition, it also remains distributed to the poor, although the number is not great. The fisherman's habit of giving fish to family and neighbors still remains valid in the Madello, but has diminished in the island Sabangko and because Salemo fishermeen in the Islands has switched to catching crab to market and export needs. Need a place to stay for the new couples can be helped by parents/in-laws that provides a place inside the house or in the space under the house. As for the home improvement poor people who still carried out cooperatively. About the cost of the restoration of health and childbirth, people are still helped by donations from family and neighbors. As for the cost of education to school children, there is still a voluntary assistance, based on the teachings of Islam (shadoqah) of the family and the community, and on the island of Salemo there employment opportunities provided by employers of crab.

The basis of helps that has been discussed in the section above, especially sourced from the customary and religious (Islamic) rules.

\section{REFERENCES}

[1] A. Arifin, Nelayan dalam Perangkap Kemiskinan (Studi Strukturasi Patron-Klien dan Perangkap Kemiskinan pada Komunitas Nelayan di Desa Tamalate, Kec. Galesong Utara, Kab. Takalar, Provinsi Sulawesi Selatan). Makassar: Disertasi Pascasarjana Universitas Negeri Makassar, 2012.

[2] A.H. Bakari, "Traditional Sosial Security as Practised in Contemporary Tanzania'sUrban Centres", in F. von Benda-Beckmann, K. von BendaBeckmann (eds.) Between Kinship and The State, Sosial Security and Law in Developing Countries. Dordrecht - Holland/ Providence RIU.S.A.: Foris Publicatios, 2012.

[3] F.Von, Benda-Beckmann, K.Von Benda-Beckmann. 1984. "Rechten Sosiale Zckerheid op Ambon", Niewsbrief voor Nederlandstalige Rechtssociologen, Rechtsantropologen en Rechtpsikologen (NNR), 5/2:262-281.

[4] F.Von, Benda-Beckmann, K.Von, et.al. 1988. "Introduction: Between Kinship and the State". In Between Kinship and the State: Social Security and Law in Developing Countries. Dordreekt-Holland/ Providence RI-USA: FORIS PUBLICATIONS.

[5] Depsos RI. 2005 Rencana Strategis Penanggulangan Kemiskinan Program Pemberdayaan Fakir Miskin.Tahun 2006-2010.

[6] J.P. Getubig, and Sonke Schmidt (eds).. Rethinking Sosial security Reaching Out to The Poor. Malaysia: S.P.Muda Printing Sdn. Bhd. Kualalumpur, 1992.

[7] M.I. Islamy, Desain Pemberdayaan Masyarakat Nelayan dalam Pengentasan Kemiskinan di Indonesia. Kerjasama Depsos RI dengan Universitas Brawijaya Malang, 2005.

[8] J. Midgey, Sosial Security, Inequality and the Third World. London: John Wiley \& Sons, 1984.

[9] B. Soeradji, and Mubyarto, Gerakan Penanggulangan Kemiskinan, Laporan Penelitian di Daerah-Daerah. Jakarta: Aditya Media, 1998.

[10] M. Tang, Aneka Ragam Pengaturan Sekuritas Sosial di Bekas Kerajaan Berru Sulawesi Selatan, Indonesia, Wageningen Nederland: Grafich Service Centrum Van Gils B. V., 1996.

[11] M. Tang, Kajian Sekuritas Sosial Bagi Keluarga Nelayan Miskin di Kota Parepare Sulawesi Selatan, Kota Baubau Sulawesi Tenggara, dan Kota Ternate Maluku Utara. Jakarta: Pusat Penerbitan Penelitian Permasalahan Kesejahteraan Sosial RI, 2005. 
[12] M. Tang, Kajian Sistem Budaya Maritim yang Mendasari Sekuritas Sosial Pada Komunitas Nelayan di Pesisir Pantai dan Pulau-Pulau Kecil di Sulawesi Selatan. LP2M 2016.

[13] M. Tang, Kajian Sekulitas Sosial Untuk Perempuan Rawan Sosial Ekonomi pada Komunitas Nelayan di Pesisir Pantai dan Pulau Kecil Sulawesi Selatan. LP2M UNHAS: Penelitian Unggulan Perguruan Tinggi, 2017. 